\title{
Impact of Different Training and Development Programs on Employee Performance in Bangladesh Perspective
}

\author{
Rashed Al Karim \\ School of Business, East Delta University, Bangladesh
}

* Corresponding author:

\begin{abstract}
The quality of the human resource of an organization is essential to its success. Thus, every organization must seek to improve the quality of its workforce. One way of achieving this is through training and development programs. The importance of training and development programs can only be appreciated with a clear understanding of its direct impact on employee performance. The purpose of this study is to determine the impact of training and development programs on employee performance. The data for this study has been collected through structure questionnaire by conducting survey. The sample size of this study is 100 and is chosen based on convenience sampling technique from different chemical and manufacturing industries of Bangladesh. All the data of this study were processed and analysed through SPSS 20. The value of Cronbach Alpha was 0.725 , means that the data of this study is reliable according to Nunnaly, (1978). Hypotheses were tested through multiple regression analysis. From the findings it has found that Orientation Training (OT), Career Development Training (CDT), and Environment, Health \& Safety Training (EHST) have significant impact on Employee Performance (EP) while there has no significant relation between Job Training (JT) and Employee Performance (EP). Eventually, this study was concluded by providing few recommendations for organisational implication
\end{abstract}

Keywords: Training \& Development, Job Training, Orientation Training, Career Development Training, Environment, Health \& Safety Training, Employees Performance.
ARTICLE INFORMATION

Received: 20 December 2018 Revised: 16 January 2019 Accepted: 05 February 2019

DOI:

10.31580/ijer.v1i2.497

\section{INTRODUCTION}

In today's modern competitive business environment, organizations are facing emerging challenges in the form of acquisition and optimization of human resource. In addition, organizations are also facing increased competition due to globalization, changes in technology, political and economic environments (Evans, Pucik \& Barsoux, 2002). In the bid to overcome these challenges, there has generally been the need for a comprehensive human resource management (HRM) practices to convert organization's human resources into a sustainable competitive advantage. Therefore, one way of prompting these organizations is to train their employees properly to enhance their performance (Aboyassin \& Sultan, 2017). Because employees are considered as a bloodstream, most valuable assets, and fundamental source of competitive advantage in the organizations (Elnaga \& Imran, 2013). Thus, preparing is essential with the end goal to get qualified workforces who are actually and socially able and equipped for vocation advancement into expert or the executive's positions (Mullins, 2010; Antwi et al., 2016).

In any organisation, the needs of training rise when there is the need to improve or adapt/adjust to changes and solve problems in order to improve on both employee and organizational performance (Getahun, 2018). The purpose of a training needs identification program therefore is to identify the gap that exist between the required and the actual competencies expected of organizations and employees so as to determine the kinds of training that can help bridge the gap (Asare-Bediako, 2002). According to Krietner (1995), no matter how carefully job applicants are screened, typically a gap remains between what the employee does know and what they should know. There can be both a negative and positive relationship between what should happen and what actually happens in terms of the work performance in any organization. There is therefore the need for every organization to adopt strategies in order to achieve the desired targets or standards set by the company. Training can be one tool that organizations can use to reach their targets or standards. Because training enhances skills, knowledge, attributes and competencies and ultimately worker performance and productivity in organizations (Cole, 2002). Several prior studies also evidenced a positive link between training \& development and employee performance, as training brings benefits for the employee along with for the firm by positively impacting employee performance through the enhancement of employee's competencies and behaviour. Firms that focus on shareholders and customer satisfaction realised the importance of investing in training, and thus recognize the worth of employee development (Evans et al., 1999).

According to Hogarh (2012), the importance of training can only be estimated with a clear understanding of its direct effect on employee's performance. An improvement in employee's performance also leads to an improvement in the organization's performance. Almost everyone now admits the importance of training on the success and growth of organizations (Jagero et al., 2012). On the other hand, the failure of organisations in their training programs can lead to many problems due to their inability to cope with the challenges of the competitive environment. Otuko, et al. (2013) 
considered that many organizations are unsuccessful because their employees not trained well enough in skills that actually matter in the age of information. Training programs assists in making knowledge of employees with more advance technology and obtaining powerful competencies and skills in order to handle the functions and basics of recently introduced technical equipment's (Farooq \& Khan, 2011). Thus, training is needed to raise employee's performance, if employees are trained they will be aware of their job specifications, skills necessary to do job and be capable to use new technology (Khan, 2012). In Bangladesh, only a few organizations have engaged in training and development of its staff and have departments, units and sectors that cover training and development. Thus, this study will try to explore the rapport of employee training and development and the employee performance in Bangladesh context. More specifically, what impacts does the organization's Training and Development have on its employee performance?

\section{TRAINING \& DEVELOPMENT AND ITS DESIRES}

According to Sari (2009), training and development is seen as one of the key practices of human resource management and it refers to the programs designed to teach the employees about the company essentials, educate them on the general rules of an organization, to provide them technical knowledge which is considered important to complete the job tasks effectively and to eradicate the probable imperfections at work. Training can be defined as a "systematic process of acquiring knowledge, skills, abilities, and the right attitudes and behaviours to meet job requirements" (Gomez-Mejia et al., 2007). Similarly, Cole, (2002) defined training as a learning activity which is directed towards the acquisition of specific knowledge and skills for an occupation or task. De Cenzo and Robbins (1996) explained that training is basically a learning experience, which seeks a relatively permanent change in an individual's skills, knowledge, attitudes or social behaviour. Hence, the essentials parts of a worthy employee training program are constructed on orientation, management skills, and operational skills of employees which the groundwork of any employee development program (Kleiman, 2000). Therefore, by focusing on specific skills required for the current need, training has been reckoned to help employees do their current jobs or help meet current performance requirement. Each new employee must be properly trained not only to develop technical skills, but to make them an integral part of the organization. Additionally, training not only develops the capabilities of the employee but sharpen their thinking ability and creativity to take better decision in time and in more productive manner (Abbas, 2014). Moreover, it additionally empowers workers to manage the client in a compelling way and react to their dissensions in auspicious way (Hollenbeck, Derue \& Guzzo, 2004). Additionally, training develops self-efficacy and results in superior performance on job, by replacing the traditional weak practices by efficient and effective work-related practices (Kathiravan, Devadason \& Zakkeer, 2006). Thus, it is very difficult for an employee to perform well at the job place without any pre-training (Garavan, 1997). Simultaneously, it is very obligatory for any organisation to give its employees training to get overall goals of the organization in a better way (Kaynak, 2003). Training and development programs increase the overall performance of the organization (Shepard Jon et al., 2003) although it is expensive to offer preparing to the representatives however over the long haul it gives back more than it took (Flynn et al., 1995; Kaynak, 2003).

\section{BENEFITS OF TRAINING \& DEVELOPMENT IN EMPLOYEE AND ORGANISATION PERSPECTIVE}

It is acknowledged undoubtedly that different types of organisational training and development programs are always beneficial not just for the organisation itself but also to the individual employees. On the one hand, training and development leads to improved profitability and more positive attitudes toward profit orientation, improves the job knowledge and skills at all levels of the organization, improves the morale of the workforce and helps the employees identify with organizational goals (Sims, 1990). On the other hand, training and development benefits individual employees through helping them make better decisions and effective problem solving, assisting in encouraging and achieving self-development and self-confidence, helping an employee a person handles stress, tension, frustration, and conflict, increasing job satisfaction and recognition and moving the person toward personal goals while improving interaction skills (Sims, 1990). Among the many benefits of training and development programs, it can eliminate risks of an organizations because the trained personnel will be efficient, thus will be able to make better use of the organizations property thereby reducing and avoiding waste. Training will also make the employees feel a sense of security thus labour turnover can be avoided. Thus, training can achieve lower cost of production and lower turnover (Cole, 2002).

Moreover, organisation's training and development programs enhance employees' competencies because through training and development programs they learn the diverse effective soft and technical skills which they required for their jobs (Feldman, 2000). Hence in line with Gerbman, (2000), employee training and development program help employees to survive in the future and develop their abilities to cope with new technologies. Employee satisfaction is one more benefit of effective training and development programs in the organisation. According to Garger (1999), employees have no feeling about their organizations, if they think that their organizations are not caring about them. Companies which are providing the training and development programs for their employees are achieving high level of employee satisfaction and low employee turnover (Wagner, 2000). Training increase organization's reliability since employees recognize their organization is spending in their future career (Rosenwald, 2000). Besides, Barber (2004) reveals that on-the-job training headed to superior novelty and implicit skills. Technical and professional skills are very important for the employees to perform a job in an effective way. Therefore, providing training opportunities to employees can enhance the performance of the employees Satterfield \& Hughes 2007; Kraiger, 2002; Barber 2004).

On the other hand, employee training and development programs are important for any organisation to stay solvent and competitive in the market, though cost is involved, but this investment is positive for the organizations to hold the place in the market (Fenn, 2000). For example, several giant organisations, like Microsoft and General Electric Company, are apprehended training opportunities as an investment (Kleiman, 2000). Employee training and development programs not only increase the profit of organizations but also provide difference within their native market. Concurrently, Bartel (2000), and Schuler and MacMillan (1984) stated that investment in training and development programs can be justified by the impact it creates to developed individual and organizational effectiveness. Additionally, varies prior investigations have also mentioned about the interconnection between training and development programs and effectiveness of the organization (Blundell et al., 1999; Bartlett 2001). In the same way, several studies (such as Logan, 2000; Rosenwald, 2000) have also confirmed strong relationship between employee training and development, and employee retention. Therefore, companies which are providing effective training and development programs to their employees are getting success in retaining them. Hence employee retention is a volunteer move by organizations to create an environment which involves employees for long term. To retain employees, organizations need to think seriously about their investment in training and development (Chaminade, 2007).

\section{TRAINING \& DEVELOPMENT AND EMPLOYEE PERFORMANCE}

According to Guest (1997) training and development program is one of the vital human resource management practices that affect the value of the workforce's knowledge, capability and skill positively. Ultimately, the effects are higher on employees' job performance and creating super companies. Tzafrir (2005) also asserted strongly that, training is an important element in producing the human capital. 
Investing in training programs can make employees feel indebted to the company. Training is necessary for the employees to perform particular job because most jobs require specific skill and knowledge by which the job is much easier to perform as it is in the benefit of the employee. Qureshi (2007) concluded that training as an HRM practice has a very positive impact on the performance of the employees since a highly positive correlation was found in that study. Valle et al. (2009) intimated without mincing words the provisions training equips employees with in terms of skills, abilities and knowledge required by their various positions. These studies have encouraged organisations in their commitment to employees' training \& development. Cheng and Ho (2001) also discussed the relevance of training and its considerable effect on job performance. According to authors, while employee performance is one of the crucial measures emphasized by the top management, employees are more concerned about issues on their own output and are increasingly aware of the accelerated obsolescence of knowledge and skills in their turbulent environment. As the literature suggests, by continuously training and developing employees effectively, they will become more aligned for career growth and career potential enhances personal motivation (Cheng \& Ho, 2001). As said by Guest (1997) mentioned in his study that training and development programs positively affects the quality of the workers knowledge, skills and capability and thus results in higher employee performance on job.

According to Swart et al., (2005), bridging the performance gap refers to implementing a relevant training intervention for the sake of developing particular skills and abilities of the workers and enhancing employee performance. He further elaborates the concept by stating that training facilitates organization to recognise that its workers are not performing well and a thus their knowledge, skills and attitudes needs to be moulded according to the firm needs. There might be various reasons for poor performance of the employees such as workers may not feel motivated anymore to use their competencies, or maybe not confident enough on their capabilities, or they may be facing work- life conflict. Similarly, as stated by Wright and Geroy (2001), employee competencies change through effective training programs. It not only improves the overall performance of the employees to effectively perform the current job but also enhance the knowledge, skills an attitude of the workers necessary for the future job, thus contributing to superior organizational performance. Through training the employee competencies are developed and enable them to implement the job-related work efficiently and achieve firm objectives in a competitive manner. Besides, Eisenberger et al. (1986) stated that workers feel more committed to the firm, when they feel organizational commitment towards them and thus show higher performance. In addition, Ahmad and Bakar (2003) concluded that high level of employee commitment is achieved if training achieves learning outcomes and improves the performance, both on individual and organizational level which are like the results of Kim (2006), Swart et al. (2005) and Bartel's (2000) study.

In the same vein, Scott, Clothier and Spriegel (1977) claimed that training practice is have a strong bond with all other human resource practices as it enables employees to develop themselves within the firm and raise their market value in the market. Moreover, Sanyal and Hisam (2018) believed that training supports to shape employees' jobrelated behaviour and facilitate them to participate for the success of the organization and ultimately firm gets higher return due to superior performance of its employees. Mamoria (1995) further mentioned that a well-trained worker is able to make a best use of organizational resources along with minimum level of wastages. As stated by Ohabunwa (1999), at the point when workers are all around prepared association can assign duty and specialist to them with full certainty of guaranteeing hierarchical achievement. Although the above literature provides the evidences regarding the benefits of training and its positive influence on employee performance, Cheramie et al. (2007), argued that, management, mostly feel hesitant while investing in its human resource due to various reasons. Sometime, despite receiving effective and timely training programs, employees are intended to cash it for the sake of their own market value and employment opportunity, or willing to change job just because of higher salaries, and thus, firm investment in training results as a cost rather than profit. It is also observed that due to the resistance of the organization towards offering training, propels individuals to invest themselves for their career development and greater performance (Baruch, 2006). From the above discussion, it is evident that there is a relationship between Training \& development and employee performance. Based on the literature review and the study objectives, the following hypothesis was proposed for this study:

$\mathbf{H}_{\mathbf{1}}$ : There is a significant relationship between the training and development (job training, orientation training, career development training \& environment, health and safety training) and the employee performance.

\section{DATA COLLECTION, QUESTIONNAIRE DESIGN, SAMPLING TECHNIQUE AND SAMPLE SIZE}

In this study, the primary data were collected conduction face to face survey through structured questionnaire with predefined answer. The study questionnaire contains 33 questions and was divided into 6 parts which are: Demographic Part: Q1-Q5, Job Training Q6-Q11, Orientation Training Q12-Q16, Career Development Training Q17Q22, Environment, Health and Safety related Training Q23-Q27, Organization Performance Q28-Q33 (shown in appendix). A nonprobability convenience sampling technique was used to select respondents from the different organisations such as chemical industry and manufacturing industry in Bangladesh. A total of 130 questionnaires were distributed to the target respondents in the mentioned organisations by following convenience sampling technique. The survey generated a total of 112 responses out of 130 questionnaires and the response rate was $86.15 \%$ where 100 responses were useable, and the valid response rate was $76.92 \%$, shown in table1 .

Table-1: Response Rate of the Questionnaire

\begin{tabular}{ll}
\hline Response Details & Rate/Frequency \\
\hline Questionnaire Distributed & 130 \\
Questionnaire Returned & 112 \\
Questionnaire Not Returned & 18 \\
Questionnaire Returned in Usable Condition & 100 \\
Questionnaire Returned in Non-Usable Condition & 12 \\
Response Rate & $86.15 \%$ \\
Valid Response Rate & $76.92 \%$ \\
\hline
\end{tabular}

\section{MEASUREMENT OF VARIABLES AND SCALING}

This study consists of four independent variables such as job training (JT), orientation training (OT), career development training (CDT), and environment, health \& safety training (EHST) and one dependent variable employee performance (EP). To measure the dependent and independent variables of the present study, all the items are adapted from three prior studies such as Falola, Osibanj and Ojo (2014), Appiah (2010), and Tahir et al. (2014). The details of the measurement of the variables are presented in the table- 2 .

Table-2: Measurement of Variables

\begin{tabular}{|c|c|c|}
\hline Variables & Items & Sources \\
\hline \multirow{5}{*}{$\begin{array}{l}\text { Job } \\
\text { Training (JT) }\end{array}$} & Develop skills & \multirow{5}{*}{$\begin{array}{l}\text { Falola, et al., } \\
\text { (2014) } \\
\text { Appiah, (2010) } \\
\text { Tahir et al. (2014) }\end{array}$} \\
\hline & Bring right attitude & \\
\hline & Understand job responsibilities & \\
\hline & $\begin{array}{l}\text { Teaches techniques to perform } \\
\text { assigned job }\end{array}$ & \\
\hline & $\begin{array}{l}\text { Reduces stress of job } \\
\text { responsibilities }\end{array}$ & \\
\hline \multirow{3}{*}{$\begin{array}{l}\text { Orientation } \\
\text { Training (OT) }\end{array}$} & $\begin{array}{l}\text { Introduced to the organization } \\
\text { Ideas about organizational culture }\end{array}$ & \multirow{3}{*}{$\begin{array}{l}\text { Falola, et al., } \\
\text { (2014) } \\
\text { Appiah, (2010) } \\
\text { Tahir et al. (2014) }\end{array}$} \\
\hline & $\begin{array}{l}\text { Understand the organizational } \\
\text { values }\end{array}$ & \\
\hline & about organizational & \\
\hline
\end{tabular}




\section{mission}

Abide by the organizational rules

and regulation

Enhances the level of competency

$\begin{array}{ll}\text { Career } & \text { Boost up morality and ethics } \\ \text { Development } & \text { Cope up with future changes } \\ \text { Training } & \text { Develop managerial skills } \\ \text { (CDT) } & \text { Increases opportunity for promotion } \\ & \begin{array}{l}\text { Ensures personal growth and } \\ \text { development }\end{array} \\ \text { Environment, } & \text { Reduction of energy consumption }\end{array}$

Health \&

Safety Knowledge about fire safety

Training Knowledge about personal safety

(EHST) and hazard

Maintain green office activities

Achieve professional goals and objectives

To be co-operative with fellows

Employee

Communicate effectively with

Performance others

(EP)

Focus on the assigned job

Increase productivity and efficiency

Contribute to better performance of the organization

Under the variable job training (JT), there are six items to measure the impact of job training on employee performance. And accordingly, the variable orientation training (OT) is measured by five items while the two other independent variables such as career development training (CDT) and environment, health \& training (EHST) are measured by six and five items respectively. On the other hand, the only dependent variable of this study employee performance (EP) is measured by six items. Moreover, all these items are scaled in a five-point Likert scale starting from strongly disagree-1, disagree-2, neither disagree nor agree-3, agree- 4 and strongly agree- 5 .

\section{STATISTICAL TOOLS}

To analyse the research data, SPSS has been used to do regression analysis. More specifically, regression analysis helps one understand how the typical value of the dependent variable (or 'criterion variable') changes when any one of the independent variables is varied, while the other independent variables are held fixed (Bolin, 2014).

\section{FINDINGS \& ANALYSIS}

\section{Demographic Profile of the Respondents}

The demographic part of questionnaire consists of five questions such as: Age, Gender, Educational Qualifications, Length of Services and Designations.

Table-3: Respondent's Demographic Profile

\begin{tabular}{|c|c|c|c|c|}
\hline $\begin{array}{l}\text { Demographi } \\
\text { cs }\end{array}$ & Category & $\begin{array}{l}\text { Frequen } \\
\text { cy }\end{array}$ & $\begin{array}{l}\text { Percenta } \\
\text { ge }\end{array}$ & $\begin{array}{l}\text { Valid } \\
\text { Percentage (\%) }\end{array}$ \\
\hline \multirow{3}{*}{ Gender } & Male & 64 & 64.0 & 64.0 \\
\hline & Female & 36 & 36.0 & 36.0 \\
\hline & Total & 100 & 100.0 & 100.0 \\
\hline \multirow{6}{*}{ Age } & $21-30$ Yrs & 17 & 17.0 & 17.0 \\
\hline & $31-40$ Yrs & 53 & 53.0 & 53.0 \\
\hline & 41-50 Yrs & 25 & 25.0 & 25.0 \\
\hline & $51-60$ Yrs & 4 & 4.0 & 4.0 \\
\hline & $>60$ Yrs & 1 & 1.0 & 1.0 \\
\hline & Total & 100 & 100.0 & 100.0 \\
\hline \multirow{4}{*}{ Education } & $\begin{array}{l}\text { Higher } \\
\text { Secondary }\end{array}$ & 1 & 1.0 & 1.0 \\
\hline & Bachelor & 47 & 47.0 & 47.0 \\
\hline & $\begin{array}{l}\text { Post } \\
\text { Graduate }\end{array}$ & 52 & 52.0 & 52.0 \\
\hline & Total & 100 & 100.0 & 100.0 \\
\hline $\begin{array}{l}\text { Length of } \\
\text { Service }\end{array}$ & $\begin{array}{l}\text { less than } 5 \\
\text { Yrs }\end{array}$ & 18 & 18.0 & 18.0 \\
\hline
\end{tabular}

\begin{tabular}{lllll} 
& $5-10$ Yrs & 27 & 27.0 & 27.0 \\
& $10-15$ Yrs & 50 & 50.0 & 50.0 \\
& above 20 Yrs & 5 & 5.0 & 5.0 \\
& Total & $\mathbf{1 0 0}$ & $\mathbf{1 0 0 . 0}$ & $\mathbf{1 0 0 . 0}$ \\
& DGM & 9 & 9.0 & 9.0 \\
& Sr. Manager & 19 & 19.0 & 19.0 \\
& Asst. & 22 & 22.0 & 22.0 \\
& Manager & 23.0 & 23.0 & 23.0 \\
& Sr. Officer & 23 & 27.0 & 27.0 \\
& Asst. & 27 & 27.0 & $\mathbf{1 0 0 . 0}$ \\
\hline
\end{tabular}

The table- 3 demonstrations that $64 \%$ of the respondents are male while females account for $36 \%$, that is, most of the workers working in the mentioned organisations are males. Further, most of the respondents i.e. $53 \%$ of the respondents, belong to the age group of 31-40 years, the second highest respondents are from 41-50 years group, which is $25 \%$ of the total respondents. And followed by $17 \%$ respondents belong to 21-30 years group, $4 \%$ respondents are from 51-60 years age group and the least number of respondents is in age group of 60 or above, which is only $1 \%$. Furthermore, education wise comparison supports the point that most of the employees belong to the highest in hierarchy. Maximum numbers of employees have the highest education, i.e., $52 \%$ of the employees have completed their graduation. And then, $47 \%$ of the respondents have completed their degree of bachelor. In terms of work experience, the findings reveal that most of the respondents have 10-15 years good work experience, which is $50 \%$ of the respondents and $27 \%$ of the respondents have 510 years of work experience in the same organisation. On the other hand, the maximum numbers of employees are working as assistant officer, which is $27 \%$ of the respondents. The second highest employees are represented as Sr. Officer, which accounts for $23 \%$ of the employees of the study sample size and afterward $22 \%$ of the respondents are Assistant Managers, 19\% of the respondents are Sr. manager and $9 \%$ are DGM of the company.

\section{Reliability Test}

In agreement with Nunnaly (1978), the value of Cronbach's alpha should be 0.700 or above. But some of the studies also considered 0.600 as an acceptable value (Gerrard, Cunningham, \& Devlin 2006). In addition, Hair et al., (2014) opined that if the Cronbach alpha is less than 0.60 , it is considered poor, while it is acceptable at 0.70 ; whereas, for Cronbach alpha over 0.80 is more reliable.

Table-4: Reliability Statistics

\begin{tabular}{lll}
\hline Variables & Cronbach's Alpha & No. of Items \\
\hline JT & 0.623 & 6 \\
OT & 0.760 & 5 \\
CDT & 0.739 & 6 \\
ESHT & 0.794 & 5 \\
EP & 0.711 & 6 \\
Average & 0.725 & 28 \\
\hline
\end{tabular}

In this study, the value of Cronbach's alpha is 0.725 (from table4) which is reliable as the value is more than 0.70 and exceeds Hair et al (2014) and Nunnaly's (1978) benchmark. Thus, it can be concluded that the measures used in this study are valid and reliable.

\section{Descriptive Statistics Analysis}

Table-5 has shown that the statistical description of study variables where it has found that Employee performance (EP) perceived by Career Development Training (CDT) with the highest mean scores, (i.e. $\mathrm{M}=3.9983, \mathrm{SD}=0.49549$ ) to be the most dominant training that evident to a considerable extent, environment, health \& safety training (EHST) $(\mathrm{M}=3.9860, \mathrm{SD}=0.58690)$ and Orientation training $(\mathrm{OT})(\mathrm{M}=3.9500, \mathrm{SD}=0.37322)$ which were rated as moderate practices of their organizations. Job training $(\mathrm{JT})(\mathrm{M}=$ $3.8150, \mathrm{SD}=0.48019$ ) with the lowest mean score was perceived on 
the overall as least dimension of training and development. The standard deviations were quite high, indicating the dispersion in a widely-spread distribution. This means that the effects of training \& development on employee performance approximate a normal distribution. This also indicates that respondents were in favour of training and development.

Table-5: Descriptive Statistics

\begin{tabular}{llll}
\hline Variables & Mean & Std. Deviation & N \\
\hline JT & 3.8150 & .48019 & 100 \\
OT & 3.9500 & .37322 & 100 \\
CDT & 3.9983 & .49549 & 100 \\
EHST & 3.9860 & .58690 & 100 \\
\hline
\end{tabular}

\section{Result of Hypothesis}

From table-6, it has been seen that $\mathrm{R}$ value is 0.626 . Therefore, $\mathbf{R}$ value (.626) for the overall Training and Development (namely Job Training, Orientation Training, Career Development Training and EHS Training) suggested that there is a strong effect of these four independent variables on the Employee performance. From the table6 it is also observed that the coefficient of determination i.e. the Rsquare $\left(\mathbf{R}^{2}\right)$ value is $\mathbf{0 . 3 9 2}$, which representing that $\mathbf{3 9 . 2 \%}$ variation of the dependent variable (Employee Performance) is due to the independent variables (Training and Development), which in fact, is a strong explanatory power of regression.

Table-6: Model Summary

\begin{tabular}{|c|c|c|c|c|c|c|c|c|c|}
\hline \multirow[b]{2}{*}{$\begin{array}{l}\text { Mo } \\
\text { del }\end{array}$} & \multirow[b]{2}{*}{$\mathbf{R}$} & \multirow[b]{2}{*}{$\begin{array}{l}R \\
\text { Sq } \\
\text { uar } \\
\text { e }\end{array}$} & \multirow[b]{2}{*}{$\begin{array}{l}\text { Adju } \\
\text { sted } \\
\mathbf{R} \\
\text { Squ } \\
\text { are }\end{array}$} & \multirow[b]{2}{*}{$\begin{array}{l}\text { Std. } \\
\text { Error } \\
\text { of } \\
\text { the } \\
\text { Esti } \\
\text { mate }\end{array}$} & \multicolumn{4}{|c|}{ Change Statistics } & \multirow[b]{2}{*}{$\begin{array}{l}\text { Sig. } \\
\text { F } \\
\text { Cha } \\
\text { nge }\end{array}$} \\
\hline & & & & & $\begin{array}{l}\mathrm{R} \\
\text { Squ } \\
\text { are } \\
\text { Cha } \\
\text { nge }\end{array}$ & $\begin{array}{l}\text { F } \\
\text { Cha } \\
\text { nge }\end{array}$ & $\begin{array}{l}\mathrm{df} \\
1\end{array}$ & $\begin{array}{l}\mathrm{df} \\
2\end{array}$ & \\
\hline 1 & $\begin{array}{l}.6 \\
26 \\
a\end{array}$ & $\begin{array}{l}.39 \\
2\end{array}$ & .367 & $\begin{array}{l}.3715 \\
5\end{array}$ & $\begin{array}{l}.39 \\
2\end{array}$ & $\begin{array}{l}15.3 \\
38\end{array}$ & 4 & $\begin{array}{l}9 \\
5\end{array}$ & .000 \\
\hline
\end{tabular}

a. Predictors: (Constant), EHST, CDT, OT, JT

Table-7: ANOVA $^{\mathrm{a}}$

\begin{tabular}{lllllll}
\hline \multicolumn{2}{l}{ Model } & $\begin{array}{l}\text { Sum of } \\
\text { Squares }\end{array}$ & df & $\begin{array}{l}\text { Mean } \\
\text { Square }\end{array}$ & $\mathbf{F}$ & Sig. \\
\hline \multirow{4}{*}{$\mathbf{1}$} & Regression & 8.470 & 4 & 2.117 & 15.338 & $.000^{\mathrm{b}}$ \\
& Residual & 13.115 & 95 & .138 & & \\
& \multicolumn{1}{l}{ Total } & 21.584 & 99 & & & \\
\hline
\end{tabular}

a. Dependent Variable: EP

b. Predictors: (Constant), EHST, CDT, OT, JT

From the table-7, it is identified that the value of F-stat is 15.338 and is significant as the level of significance is less than $5 \%(\mathrm{p}<$ 0.05 ). This indicates that the overall model was reasonable fit and there was a statistically significant association between training and development and employee performance (EP). Additionally, this also indicated that the null hypothesis is rejected, and alternative hypothesis is accepted. Hence it can be concluded that training and development has significant impact on employee performance of Bangladeshi manufacturing and chemical industries. In the table- 8 , the unstandardized coefficients indicated how much the dependent variable varies with an independent variable, when all other independent variables are held constant. The beta coefficients indicated that how and to what extent training and development such as Job Training (JT), Orientation Training (OT), Career Development Training (CDT) and Environment, Health \& Safety Training (EHST) influence the performance of the Employees. It has been found that, Career Development Training (beta $=0.568=, \mathrm{t}=7.018, \mathrm{p}<0.05$ ) and Orientation Training (beta $=0.215, \mathrm{t}=2.651, \mathrm{p}<0.05$ ) have the highest importance on Employee performance, whereas, EHS Training (beta $=0.212, \mathrm{t}=2.589, \mathrm{p}<0.05$ ), Job Training (beta $=0.041, \mathrm{t}=0.499$, $\mathrm{p}>0.05$ ) have a relatively lower impact on the performance of organizations.

\begin{tabular}{|c|c|c|c|c|c|c|c|c|}
\hline \multicolumn{9}{|c|}{ Table-8: Unstandardized Coefficients ${ }^{a}$} \\
\hline \multirow{2}{*}{\multicolumn{2}{|c|}{ Model }} & \multicolumn{2}{|c|}{$\begin{array}{l}\text { Unstandard } \\
\text { ized } \\
\text { Coefficient } \\
\mathrm{s}\end{array}$} & \multirow{2}{*}{$\begin{array}{l}\text { Standard } \\
\text { ized } \\
\text { Coefficie } \\
\text { nts } \\
\text { Beta } \\
\end{array}$} & \multirow[t]{2}{*}{$\mathbf{T}$} & \multirow[t]{2}{*}{ Sig. } & \multicolumn{2}{|c|}{$\begin{array}{l}\text { Collinearity } \\
\text { Statistics }\end{array}$} \\
\hline & & B & $\begin{array}{l}\text { Std. } \\
\text { Error }\end{array}$ & & & & $\begin{array}{l}\begin{array}{l}\text { Toler } \\
\text { ance }\end{array} \\
\end{array}$ & VIF \\
\hline \multirow{5}{*}{1} & $\begin{array}{l}\text { (Consta } \\
\text { nt) }\end{array}$ & .080 & .647 & & .123 & .902 & & \\
\hline & JT & .040 & .079 & .041 & .499 & 619 & .963 & 1.038 \\
\hline & OT & .269 & .102 & .215 & 2.651 & .009 & .969 & 1.032 \\
\hline & CDT & .535 & .076 & .568 & 7.018 & .000 & .977 & 1.024 \\
\hline & EHST & .169 & .065 & .212 & 2.589 & .011 & .955 & 1.047 \\
\hline
\end{tabular}

From the table- 8 , it is also specified that out of four independent variables, three independent variables such as Orientation Training (OT) $(\mathrm{p}=0.009)$, Career Development Training $(\mathrm{CDT})(\mathrm{p}=0.000)$ and Environment, Health \& Safety Training (EHST) $(p=0.011)$ have significant impact on employee performance (EP) as the level of significant is less than $(\mathrm{p}<0.05)$ while one variable, Job Training (JT) is not significant as the $P$ value $(p=0.619)$ is higher than the acceptance level. On the other hand, multicollinearity has been checked to verify whether the degree of multicollinearity between independent variables are high. If the correlation coefficient is at 0.90 and above, multicollinearity problem exists (Hair et al. 2010). In addition, if the tolerance value of 0.10 or below and variance inflation factor (VIF) value of 10 or above show a high multicollinearity. In the table- 8 , it showed that tolerance value of all independent variables (Job, Orientation, Career Development, EHS Training) is greater than 0.10 and the variance inflation factors (VIF) value is lower than 10 , which indicates that the degree of multicollinearity between independent variables is not high.

\section{Recommendations for the Organisations}

In the light of the study findings, this study came to the decision that there should be different Training and Development programs in every organization. Although there are some disadvantages like it is costly to give training to the employees, but the advantages of Training and Development programs are much more than its disadvantages which are briefly discussed in this study. Therefore, based on the study findings, the following recommendations are proposed for the organisations in Bangladesh because if the performance of the employee is not good due to lack of proper training and development programs, it will must affect the organisation's overall performances.

- Need based training programs are to be imparted to the employees by the organizations to make them focused on the organizational goals.

- Equal opportunity for all grades of employees in the organizations is to be given to maintain homogeneous enhancement of skills and techniques.

- Career Planning and Development Schemes are to be implemented and they should be closely monitored.

- It is important for the corporate sector to understand, training does not have an impact on just employee performance but on a firm's overall performance. There should be a willingness of the organisations to invest in employee training and development programs with the understanding that it is an investment that will yield returns.

- Most of the employees do not understand the benefits of training. They take part in the training as a part of job requirement. Organisation should explain the benefits properly and motivate the employees to learn properly during the training program.

\section{CONCLUSION}

The reason for investigating the impact of employee training and development on employee performance was motivated by the 
observation that some organizations do not seem to care about improving the capacity of their workforces; they instead frown at and punish any weaknesses of workers. Training is a vital driver of the many different projects related to introducing new concepts, work methods, products and technologies. Training represents the principal instrument to increase employee's efficiency, to improve the workplace relationships, and to develop employees' skills and abilities in their relationship with corporate stakeholders. This study found that there is a positive role of training in improving the employee performance. Among the difficulties faced by training and development programs, it was discovered that temporary losses are incurred due to financial expenses, and the momentary stop of productivity. Generally, employees were greatly improved at their jobs due to these training programs. The findings of the present study indicate that there exists a strong correlation between training and development practices and Employee Performance in the selected organization. This infers that there exists a positive relationship in between training and development practices and employee performance. Organizations which invest in their employee skills by way of training and development activities will certainly reap the profits through employee productivity. Thus, it is crucial to continuously develop the employee skills to maximise employee performance. This is possible only by way of continuous training and development practices as the untrained employees could not perform up to the mark and this will certainly affect the overall performance of the organisation. In line with study findings, since training and development programs have a significant impact and influence on employee performance and productivity, so it is essential for the organisations to maintain the ambient environment which involves continuous training process. Organizations which promote training and development practices tend to possess a shining corporate image.

\section{Limitations and Recommendations for Future Study}

- The present is focused mainly on chemical and manufacturing industries, thus future study can be conducted by including more industries such as telecom industry, Readymade Garments industry, and MNCs in Bangladesh.

- There are many other variables to measure the impact of training \& development on employee performance. So future study can choose the other variables that are not present in this study.

- The sample size of this study is only 100 which may not be representative of the whole population. Therefore, future study can increase the sample size to get more accurate and reliable perceptions from the respondents.

\section{References:}

Abbas, Z. (2014). Identification of factors and their impact on employees' training and organizational performance in Pakistan. Kasbit journal of management \& social science, 7(1), 93-109.

Aboyassin, N. A., \& Sultan, M. A. (2017). The Role of Human Resources Training in Improving the Employee's Performance: Applied Study in the Five Stars Hotels in Jordan. International Journal of Business Administration, 8(5), 46

Ahmad, K. Z., \& Bakar, R. A. (2003). The association between training and organizational commitment among white- collar workers in Malaysia. International journal of training and development, 7(3), 166185

Antwi, J. O., Opoku, A. C., Seth, A., \& Margaret, O. B. (2016). Assessing the human resource management practices of public banks from employees' perspective: case study of selected branches of Ghana commercial bank, Kumasi. Global Journal of Human Resource Management, 4(1), 13-30.

Appiah, B. (2010). The impact of training on employee performance: a case study of HFC Bank (Ghana) Limited. Unpublished doctoral dissertation. Ashesi University College, Ghana.

Asare-Bediako, K. (2002). Professional skills in human resource management. Accra: Kasbed Limited.

Barber J. (2004). Skill upgrading within informal training: lessons from the Indian auto mechanic. International Journal of Training and Development, 8, 128-39.
Bartel, A.P. (2000). Measuring the Employer's Return on Investment in Training: Evidence from the Literature. Industrial Relations, 39(3), $502-524$.

Bartlett, K. R. (2001). The Relationship between Training and Organizational Commitment: A Study in the Health Care Field. Human Resource Development Quarterly, 12(4), 335-352.

Baruch, Y. (2006). Career development in organizations and beyond: Balancing traditional and contemporary viewpoints. Human resource management review, 16(2), 125-138.

Blundell, R., Dearden, L., Meghir, C. and Sianesi, B. (1999). Human Capital Investment: The Returns from Education and Training to the Individual, the Firm and the Economy. Fiscal Studies, 20(1), 1-23.

Bolin, J. H. (2014). Hayes, A. F. (2013). Introduction to Mediation, Moderation, and Conditional Process Analysis: A Regression- Based Approach. New York, NY: The Guilford Press. Journal of Educational Measurement, 51(3), 335-337.

Chaminade, B. (2007). A retention checklist: how do you rate? African Journal of Business Management, 4(10), 49-54

Cheng, E.W.L., Ho, D.C.K. (2001). The influence of job and career attitudes on learning motivation and transfer. Career Development International, 6, 20-27.

Cheramie, R. A., Sturman, M. C., \& Walsh, K. (2007). Executive career management: Switching organizations and the boundaryless career. Journal of Vocational Behavior, 71(3), 359-374.

Cole, G. A. (2002). Personnel and human resource management. Cengage Learning EMEA.

De Cenzo, D. A., \& Robbins, S. P. (1996). Human resource management. New York, USA: John Wiley\& Sons.

Eisenberger, R., Huntington, R., Hutchison, S., \& Sowa, D. (1986). Perceived organizational support. Journal of Applied psychology, 71(3), 500.

Elnaga, A., \& Imran, A. (2013). The effect of training on employee performance. European Journal of Business and Management, 5(4), 137-147.

Evans, D. J., Lindsay, M. A., Webb, B. L., Kankaanranta, H., Giembycz, M. A., O'Connor, B. J., \& Barnes, P. J. (1999). Expression and activation of protein kinase $\mathrm{C}-\zeta$ in eosinophils after allergen challenge. American Journal of Physiology-Lung Cellular and Molecular Physiology, 277(2), 233-239.

Evans, P., Pucik, V., \& Barsoux, J. L. (2002). The global challenge: Frameworks for. International Human Resource Management. New York: McGraw-Hill Irwin.

Falola, H. O., Osibanjo, A. O., \& Ojo, I. S. (2014). Effectiveness of training and development on employees' performance and organisation competitiveness in the nigerian banking industry. Bulletin of the Transilvania University of braşov, 7(1), 161.

Farooq, M., \& Khan, M. A. (2011). Impact of training and feedback on employee performance. Far east journal of psychology and business, 5(1), 23-33.

Feldman, D. (2000, May). The Dilbert syndrome: How employee cynicism about ineffective management is changing the nature of careers in organizations. American Behavioral Scientist, 43, 1286-1301.

Fenn, D. (1999, February). Corporate universities for small companies. Inc, 21 (2), 95-96

Flynn, B. B., Schroeder, R.G., \& Sakakibara, S. (1995). The impact of quality management practices on performance and competitive advantage. Decision Sciences, 26, 659-91.

Garavan, T. N. (1997). Training, development, education and learning: different or the same?. Journal of European industrial training, 21(2), 39-50.

Garger, E. M. (1999). Goodbye training, hello learning. Workforce, 78 (11), $35-42$.

Gerbman, R. V. (2000). Corporate Universities 101. HR Magazine, 45 (2), 101-106.

Gerrard, P., Barton Cunningham, J., \& Devlin, J. F. (2006). Why consumers are not using internet banking: a qualitative study. Journal of services Marketing, 20(3), 160-168

Getahun, S. M. (2018). The Effect of Training on Employees Performance: in Selected Commercial Bank. Ethiopia: Dawro Zone.

Gomez-Mejia, L. R., Balkin, D. B., \& Cardy, R. L. (2007). Managing human resources. London : Pearson/Prentice Hall.

Guest, D. E. (1997). Human resource management and performance: a review and research agenda. International journal of human resource management, 8(3), 263-276.

Hair, J. F., Black, W. C., Babin, B. J., \& Anderson, R. E. (2010). Multivariate Data Analysis (7th ed.). Upper Saddle River, New Jersey: Prentice Hall.

Hair, J. F., Hult, G. T. M., Ringle, C. M., \& Sarstedt, M. (2014). A prima on partial least squares structural equation modeling (PLS-SEM) (1st ed.). Los Angeles: Sage. 
Hogarh, J. K. (2012). The Effect of Training on Staff Performance: A Case Study of SIC Insurance Company Limited. Unpublished MBA dissertation, Kwame Nkrumah University of Science and Technology, Ghana.

Hollenbeck, J. R., DeRue, D. S., \& Guzzo, R. (2004). Bridging the gap between I/O research and HR practice: Improving team composition, team training, and team task design. Human Resource Management: Published in Cooperation with the School of Business Administration, The University of Michigan and in alliance with the Society of Human Resources Management, 43(4), 353-366.

Jagero, N., Komba, H. V., \& Mlingi, M. N. (2012). Relationship between on the job training and employee's performance in courier companies in Dar es Salaam, Tanzania. International Journal of Humanities and Social Science, 2(22), 114-120.

Kathiravan, N., Devadasas, S. R. \& Zakkeer, M. M. (2006). Quality Oriented Improvement Training, Industrial and Data Systems. Emerald Group Publishers, 106(3), 380-406.

Kaynak, H. (2003). The relationship between total quality management practices and their effects on firm performance. Journal of operations management, 21(4), 405-435.

Khan, M. I. (2012). The impact of training and motivation on performance of employees. Business review, 7(2), 84-95.

Kim, S. (2006). Public service motivation and organizational citizenship behaviour in Korea. International Journal of Manpower, 26(8), $722-$ 40 .

Kleiman, L. S. (2000). Human resource management: A managerial tool for competitive advantage. Kendall Hunt Publishing Company.

Kraiger K. (2002). Decision-based Evaluation. In Creating, Implementing, and Maintaining Effective Training and Development: State-of-the-Art Lessons for Practice, ed. K Kraiger, pp. 331-75. San Francisco, CA: Jossey-Bass.

Krietner, S. (1995). The good manager's guide. New York.

Mamoria, C. B. (1995), Personnel Management, New Delhi: Himalaya Publishing House.

Mullins, L. J. (2010). Management and Organizational Behavior $\left(9^{\text {th }}\right.$ ed.). Harlow: Edinburgh Gate.

Nunnaly, J. (1978). Psychometric theory. New York: McGraw-Hill.

Ohabunwa, S. (1999). Nigeria Business Environment in the New Millenniumpaper presented for HRDB UNILAG on Renovating our corporate management practices for the New Millemium, Wednesday 19th May.

Otuko, A. H., Chege, K., \& Douglas, M. (2013). Effect of training dimensions on employee's work performance: a case of mumias sugar company in Kakamega County. International Journal of Business and Management Invention, 2(9), 138-149.

Qureshi M, T. (2007). Impact of Human Resource Management (HRM) Practices on Employees Performance. Unpublished MBA dissertation, Muhammad Ali Jinnah University, Islamabad.

Rosenwald, M. (2000, October 15). Working class: More companies are creating corporate universities to help employees sharpen skills and learn new ones. Boston Globe.

Sanyal, S. \& Hisam, M. W. (2018). Impact of Training and Development on the Performance of Employees - A Comparative Study on Select Banks in Sultanate of Oman. International Journal of Scientific Research and Management (IJSRM), 6(3), 191-198.

Sari, F. O. (2009). Effects of employee trainings on the occupational safety and health in accommodation sector. Procedia Soc. Behav. Sci., 1, 1865-1870.

Satterfield J. M, \& Hughes, E. (2007). Emotion skills training for medical students: a systematic review. Medical Education, 41, 935-41.

Schuler, R.S., \& MacMillan, I.C. (1984). Gaining Competitive Advantage through Human Resource Management Practices. Human Resource Management, 23(3), 241-255.

Scott. C. \& Spriegel (1977). Personnel Management: Principles, practices and point of View (6 $6^{\text {th }}$ ed.). New Delhi: Tata McGraw-Hill Publishing Company Ltd.

Shepard, J. R. \& Greene, W., (2003). Sociology and You. Ohio: Glencoe McGraw-Hill.

Sims, R. (1990). An Experiential Learning Approach to Employee Training Systems. New York: Quorum Books.

Swart, J., Mann, C., Brown, S. \& Price, A. (2005). Human Resource Development: Strategy and Tactics. Elsevier Butterworth-Heinemann Publications, Oxford.

Tahir, N., Yousafzai, I. K., Jan, S., \& Hashim, M. (2014). The Impact of Training and Development on Employees Performance and Productivity A case study of United Bank Limited Peshawar City, KPK, Pakistan. International Journal of Academic Research in Business and Social Sciences, 4(4), 86.

Tzafrir, S. S. (2005). The relationship between trust, HRM practices \& firm performance. The International Journal of Human Resource
Management, 16(9), 1600-1622.

Valle, R., Martin, F., Romero, P. M. \& Dolan, S. (2000). Business strategy, work processes and human resource training: are they congruent? Journal of Organizational Behaviour, 21, 283-97.

Wagner, S. (2000,). Retention: Finders, keepers. Training and Development. $54(8), 64$.

Wright, P. C., \& Geroy, G. D. (2001). Changing the mindset: the training myth and the need for world-class performance. International Journal of Human Resource Management, 12(4), 586-600. 